\title{
Surgical treatment for pulmonary aspergilloma - early and long-term results
}

\author{
Mariusz Kasprzyk, Kornel Pieczyński, Krystian Mania, Piotr Gabryel, Cezary Piwkowski, \\ Wojciech Dyszkiewicz
}

Department of Thoracic Surgery, Poznan University of Medical Sciences, Poznań, Poland

Kardiochirurgia i Torakochirurgia Polska 2017; 14 (2): 99-103

\begin{abstract}
Introduction: Pulmonary aspergilloma is a difficult therapeutic problem due to the low effectiveness of conservative treatment and high surgical morbidity.

Aim: To analyze the early and late results of surgical treatment for pulmonary aspergilloma.

Material and methods: From 2005 to 2015, 49 patients were treated surgically for pulmonary aspergilloma. Symptoms occurred in $85.7 \%$ of cases, including recurrent hemoptysis in $53 \%$. A history of immunosuppressive therapy or chemotherapy was noted in $24.5 \%$ of patients. Complex aspergilloma was diagnosed in $79.6 \%$ of cases. Immunological test results were positive in $10.2 \%$, and bronchoalveolar lavage samples were positive for Aspergillus species in $18.5 \%$ of cases. In $59.2 \%$ of patients, the surgical risk was assessed as ASA 3. Thirty seven patients underwent lobectomy, 3 - pneumonectomy, 7 -wedge resection, 1 - decortication, and 1 - cavernostomy.

Results: In-hospital mortality was $4.1 \%$. Postoperative complications occurred in $63.3 \%$ of patients. The most common complications were: prolonged air leak (26.3\%), arrhythmias (20.4\%), residual pneumothorax $(16.3 \%)$, respiratory failure (14.3\%), atelectasis (12.3\%), and bleeding (12.3\%). Of the three patients that underwent pneumonectomy, one died, two required repeat thoracotomy because of bleeding, and all three required prolonged mechanical ventilation. Two patients died during the follow-up period. Aspergilloma did not recur in any of the patients who underwent pulmonary resection.

Conclusions: Due to the high risk of complications, surgical treatment of pulmonary aspergilloma should be restricted to symptomatic patients in whom lobectomy can be performed. The long-term results of surgical treatment are good, preoperative symptoms abate in most patients, and the rate of aspergillosis recurrence is very low.

Key words: pulmonary aspergilloma, hemoptysis, surgical treatment, complications.
\end{abstract}

\section{Streszczenie}

Wstęp: Grzybniak kropidlakowy płuca stanowi trudny problem terapeutyczny ze względu na niewielką skuteczność leczenia zachowawczego oraz duże ryzyko wystąpienia powikłań po leczeniu chirurgicznym.

Cel: Analiza wyników wczesnych i odległych leczenia chirurgicznego grzybniaka kropidlakowego płuca.

Materiat i metody: W latach 2005-2015 49 chorych leczono operacyjnie z powodu grzybniaka kropidlakowego. U 85,7\% pacjentów występowały objawy, w tym u 53\% nawracające krwioplucia. 24,5\% było wcześniej leczonych immunosupresyjnie lub przebyło chemioterapię. Grzybniaki złożone stanowiły 79,6\% przypadków. Badanie serologiczne na obecność antygenu Aspergillus było dodatnie w 10,2\% przypadków, a obecność strzępków grzyba w popłuczynach oskrzelowych stwierdzono u 18,5\% pacjentów. U 59,2\% chorych ryzyko operacyjne oceniono jako ASA 3. U 37 chorych wykonano lobektomię, u 3 pneumonektomię, u 7 resekcję klinową, u 1 częściową dekortykację płuca i u 1 kawernostomię.

Wyniki: Śmiertelność w czasie hospitalizacji wyniosła 4,1\%. Powikłania pooperacyjne wystąpiły u 63,3\% chorych. Do najczęstszych powikłań należały: przedłużony przeciek powietrza (26,3\%), zaburzenia rytmu serca $(20,4 \%)$, resztkowa komora odmowa (16,3\%), niewydolność oddechowa wymagająca przedłużonej wentylacji (14,3\%), niedodma płuca (12,3\%) i krwawienie wymagające retorakotomii (12,3\%). Spośród 3 chorych, u których wykonano pneumonektomię, 1 zmarł w okresie pooperacyjnym, u 2 wykonano retorakotomię z powodu krwawienia, wszyscy wymagali przedłużonej wentylacji. W okresie obserwacji zmarło 2 chorych, u żadnego z chorych po zabiegu resekcyjnym nie stwierdzono nawrotu grzybicy.

Wnioski: Ze względu na duże ryzyko wystąpienia powikłań leczenie chirurgiczne grzybniaka płuca należy ograniczyć do chorych z objawami choroby, u których można wykonać lobektomię. Wyniki odległe leczenia operacyjnego są dobre, u większości chorych ustępują dolegliwości, a odsetek nawrotów grzybicy jest znikomy.

Słowa kluczowe: grzybniak kropidlakowy, krwioplucie, leczenie chirurgiczne, powikłania. 


\section{Introduction}

Aspergillosis is most often caused by the fungus Aspergillus fumigatus; it occurs mainly in immunodeficient individuals and as a form of colonization of previously existing cavities in the lungs. Aspergilloma (fungus ball), one of the clinical forms of aspergillosis, develops primarily in posttuberculous cavities and may constitute a significant therapeutic problem due to recurrent hemoptysis and symptoms of chronic infection. Antifungal agent penetration into the cavity of the fungus ball is scant; therefore, in many cases, the only treatment option is to resect the pulmonary parenchyma colonized by the fungus. Notwithstanding, surgical treatment is associated with many technical difficulties and a relatively high risk of postoperative complications, particularly in patients who are emaciated or treated with immunosuppression. The question remains open whether asymptomatic patients with aspergilloma diagnosis or suspicion have to undergo surgery.

\section{Aim}

The aim of this study was to analyze the early and longterm results of surgical treatment for pulmonary aspergilloma.

\section{Material and methods}

This retrospective analysis encompassed a group of 49 patients treated with surgery due to pulmonary aspergilloma during the years 2005-2015. The study group

Tab. I. Clinical data of the study group

\begin{tabular}{|c|c|}
\hline Parameter & Result \\
\hline Age [years] & 19-74 (mean: 53) \\
\hline \multicolumn{2}{|l|}{ Sex: } \\
\hline Male & $35(71.4 \%)$ \\
\hline Female & $14(28.6 \%)$ \\
\hline \multicolumn{2}{|l|}{ Symptoms: } \\
\hline Hemoptysis & $26(53 \%)$ \\
\hline Cough & $26(53 \%)$ \\
\hline Fatigability & $10(20.4 \%)$ \\
\hline Chest pain & $9(18.4 \%)$ \\
\hline Bleeding from the bronchial tree & $3(6.1 \%)$ \\
\hline \multicolumn{2}{|l|}{ Aspergilloma: } \\
\hline Simple & $10(20.4 \%)$ \\
\hline Complex & $39(79.6 \%)$ \\
\hline $\begin{array}{l}\text { Presence of fungal hyphae in bronchial lavage } \\
\text { samples }\end{array}$ & $9(18.4 \%)$ \\
\hline Positive serological test result & $5(10.2 \%)$ \\
\hline \multicolumn{2}{|l|}{ Type of procedure: } \\
\hline Lobectomy & $37(75.5 \%)$ \\
\hline Wedge resection & $7(14.3 \%)$ \\
\hline Pneumonectomy & $3(6.1 \%)$ \\
\hline Decortication + drainage & $1(2.05 \%)$ \\
\hline Cavernostomy & $1(2.05 \%)$ \\
\hline
\end{tabular}

included 35 men and 14 women aged 19-74 years (mean: 53 years). Most patients ( $n=42)$ exhibited clinical symptoms; the most frequent symptoms were hemoptysis (53\%) and cough (53\%) (Tab. I). At least one episode of bronchial bleeding requiring urgent hospitalization was noted in $6.1 \%$ of patients, but in no case was the bleeding the cause of death or an indication for immediate surgery. Among the 49 patients, comorbidities were noted in 31; 24 (49\%) patients had a history of pulmonary tuberculosis and $5(10.2 \%)$ patients had been treated for chronic obstructive pulmonary disease (COPD). In the study group, 8 (16.3\%) patients had been previously treated with chemotherapy for neoplastic disease (3 cases of lymphoblastic leukemia, 2 - acute myeoloid leukemia, 1 - testicular cancer, 1 - lung cancer, 1 - breast cancer and acute myeoloid leukemia). Four (8.2\%) patients had been chronically treated with immunosuppressants due to rheumatoid arthritis (3 patients) or ulcerative colitis (1 patient). Three patients had previously undergone pleural drainage due to pneumothorax, and another three had been treated with thoracotomy and wedge resection due to tuberculomas. It should be noted that, according to the estimation of the operative risk using the ASA (American Society of Anesthesiologists) classification, none of the patients had an ASA score of 1; 20 (40.8\%) patients received an ASA score of 2, while 29 (59.2\%) patients received an ASA score of 3. Based on radiological examination (chest computed tomography (CT)) and intraoperative evaluation, two groups of patients were distinguished: those with simple aspergilloma (a thinwalled cavity with aspergilloma elements within unchanged pulmonary tissue) and those with complex aspergilloma (a thick-walled cavity in pathologically changed pulmonary parenchyma with clear pleural thickening and adhesions). Most patients (79.6\%) were diagnosed with complex aspergilloma. Preoperative diagnostics routinely included the following examinations: chest computed tomography (CT), bronchofiberoscopy, spirometry, evaluation of bronchial lavage samples for the presence of Aspergillus hyphae, antibody titer testing, and tests for the presence of Aspergillus antigens in peripheral blood. Fungal hyphae were found in the bronchial lavage samples of only 9 (18.5\%) patients, and the results of the immunological examination for the presence of Aspergillus antigens in blood were positive in only $5(10.2 \%)$ patients. In all patients, the presence of Aspergillus was confirmed by postoperative histopathological examinations.

The fungus ball was located in the right lung in $67.3 \%$ of cases, and in the left lung in $32.7 \%$ of cases. In most cases (57.1\%), the superior lobe of the right lung was involved. The spirometry results of most patients were normal. The mean value of forced expiratory volume in $1 \mathrm{~s}\left(\mathrm{FEV}_{1}\right)$ for the whole group was $82 \%$ of the predicted normal value (47.5-124\%), while the mean value of the Tiffeneau index (FEV $\%$ VC) amounted to 76\% (45.4-100\%). Laboratory investigation revealed anemia in 15 patients qualified for surgery $(30.6 \%)$. 
Among the 49 patients, 37 underwent lobectomy, 3 pneumonectomy, 7 - wedge resection of lung parenchyma, 1 - partial lung decortication with pleural drainage, and 1 - cavernostomy. In 3 cases, lobectomy was supplemented with wedge resection of the neighboring lobe. Resection procedures were performed under general intravenous anesthesia with separate intubation of the right and left bronchi by means of anterolateral thoracotomy. In 1 case, the lobectomy was performed using videothoracoscopy. Perioperatively, routine antithrombotic prophylaxis (lowmolecular-weight heparin) and antibiotic therapy ( $3^{\text {rd }}$ generation cephalosporin: one dose $30 \mathrm{~min}$ before skin incision and a second dose after $2 \mathrm{~h}$ if the procedure lasted $>120 \mathrm{~min}$ ) was provided. Antifungal agents (most frequently: itraconazole or voriconazole) were used postoperatively in 19 (38.8\%) patients.

The data pertaining to the clinical condition of patients and possible aspergillosis recurrence after the surgery were obtained from the medical documentation of outpatient pulmonological and thoracic surgery clinics.

\section{Results}

The mean duration of the procedure was $130 \mathrm{~min}$ (55-255 $\mathrm{min}$ ); intraoperative blood loss ranged from 50 to $1500 \mathrm{ml}$ (mean: $410 \mathrm{ml}$ ). No intraoperative deaths were noted. One patient after left-sided pneumonectomy, who underwent repeat surgery on the 1st postoperative day due to bleeding, died on the $4^{\text {th }}$ postoperative day due to acute respiratory distress syndrome (ARDS) and multiple organ dysfunction syndrome. One patient after right upper lobectomy was diagnosed with an esophagopleural fistula with pleural empyema during the postoperative period. The patient died on the $112^{\text {th }}$ postoperative day, having suffered from multiple organ dysfunction syndrome. No other postoperative deaths were noted (in-hospital mortality: 4.1\%). Postoperative complications occurred in 31 (63.3\%) patients. The most frequent complications were: prolonged air leak (26.3\%), supraventricular cardiac arrhythmia (20.4\%), residual pneumothorax after drain removal (16.3\%), respiratory failure requiring reintubation and mechanical ventilation (14.3\%), atelectasis of the operated lung (12.3\%), bleeding requiring repeat thoracotomy (12.3\%), circulatory failure (10.2\%), postoperative wound infection (10.2\%), and bronchopleural fistula (6.1\%) (Tab. II). The mean hospitalization time in this group was 13.2 days (4-112 days), and the mean length of intensive care unit (ICU) stay was 4 days (1-98 days). The duration of pleural drainage ranged from 2 to 20 days (mean: 5.7 days) Transfusion of packed red blood cells (PRBC) was necessary in 14 (28.6\%) cases. The number of transfused PRBC units ranged from 1 to 16 (mean: 4.6 units). Out of the 3 patients who underwent pneumonectomy, 1 died during the perioperative period, and 2 underwent repeat thoracotomy due to bleeding; they all required prolonged ventilation and PRBC transfusions.

The duration of postoperative follow-up ranged from 18 months to 11 years. Among the 49 patients who were operated on, only one suffered from aspergillosis recurrence.
Tab. II. Postoperative complications

\begin{tabular}{lc} 
Complication & Result \\
Prolonged air leak & $13(26.3 \%)$ \\
\hline Cardiac arrhythmias & $10(20.4 \%)$ \\
\hline Residual pneumothorax & $8(16.3 \%)$ \\
\hline Respiratory failure & $7(14.3 \%)$ \\
\hline Atelectasis requiring bronchial aspiration & $6(12.3 \%)$ \\
\hline Bleeding requiring thoracotomy & $6(12.3 \%)$ \\
\hline Circulatory failure & $5(10.2 \%)$ \\
\hline Wound infection & $5(10.2 \%)$ \\
\hline Bronchopleural fistula & $3(6.1 \%)$ \\
\hline Renal failure & $2(4.1 \%)$ \\
\hline Pneumonitis & $1(2.05 \%)$ \\
\hline Bleeding from the gastrointestinal tract & $1(2.05 \%)$ \\
\hline Esophagopleural fistula & $1(2.05 \%)$ \\
\hline
\end{tabular}

After 7 years from undergoing cavernostomy, the mentioned patient underwent a left-sided extrapleural pneumonectomy, which was complicated by a bronchopleural fistula; subsequently, fenestration of the post-resection cavity was performed, followed by myoplasty and thoracoplasty, resulting in successful recovery from an empyema. Two patients died during the follow-up due to neoplastic disease. In both cases, the cause of death was lung cancer, which was diagnosed 1 year and 2 years after the surgical treatment for aspergilloma. One patient underwent a left upper lobectomy due to pulmonary adenocarcinoma 4 years after the right upper lobectomy performed due to Aspergillus infection. At present, the patient remains under the supervision of an oncological outpatient clinic, showing no signs of neoplastic recurrence. In all the patients who were operated on, hemoptysis abated completely; 2 patients continued to cough for some time, expectorating small amounts of purulent secretion. One patient required pleural fenestration due to chronic empyema 6 months after undergoing a wedge resection. The pleural window was closed with myoplasty after 10 more months.

\section{Discussion}

Aspergillus fumigatus spores are widespread in the environment, and its hyphae are relatively often found in sputum samples [1]. In some individuals, Aspergillus colonization may lead to pulmonary aspergillosis, which constitutes a very challenging therapeutic problem. This pertains primarily to patients with immunodeficiency, after chemotherapy, or undergoing chronic immunosuppression therapy (mostly with steroids). In this patient group, the fungal infection may lead to the development of invasive aspergillosis with a severe clinical course [2]. In such cases, the fungal lesions in the lungs are often multifocal, and the options of surgical treatment are very limited. In the group analyzed in the present study, over $16 \%$ of patients had previously undergone chemotherapy (most frequently due to leukemia), while over $8 \%$ of patients had been 
chronically receiving immunosuppressants. Aspergilloma is a limited form of infection developing in previously existing cavities in the pulmonary parenchyma. In a study by Kim et al., aspergilloma developed in pathologically changed lung parenchyma in $82 \%$ of patients; $65 \%$ of them had previously suffered from tuberculosis [3]. Similarly, in most other publications, pulmonary tuberculosis is presented as the disease most likely to promote the development of aspergilloma (32-45\% of cases) [4-6]. In our material, Aspergillus colonization occurred in post-tuberculous cavities in $49 \%$ of patients. The Aspergillus patients also featured a relatively large proportion of patients with COPD (10\%), which is in line with the data published by other authors [7].

Of note are the diagnostic problems related to confirming the suspicion of aspergilloma. In many cases, the diagnosis is based on radiological investigation (revealing a soft-tissue mass surrounded with a crescent of air, an image typical of aspergilloma). In the analyzed group, the results of serological tests for the presence of Aspergillus antibodies in blood were positive in only $10.2 \%$ of patients, and the presence of fungal hyphae in bronchial lavage samples was established in only $18.5 \%$ of patients. Therefore, some authors believe that preoperative immunological testing is not necessary [5]. A decided majority of patients who are qualified for surgical treatment report symptoms, and the most common symptom is hemoptysis. According to most authors, the percentage of symptomatic patients exceeds $80 \%$ [1, 8-10]. In the analyzed group, this percentage amounted to $85.7 \%$. The question remains open whether all asymptomatic patients should be operated on. Due to the risk of massive hemoptysis reaching $10-20 \%$, most authors recommend performing surgery in patients with simple aspergilloma who are in good general condition $[3,11]$. The management of complex aspergilloma is more controversial. Kim et al. recommend surgery only for patients in good general condition without significant comorbidities. In emaciated patients burdened with other conditions, alternative treatment methods are advised (bronchial artery embolization, cavernostomy, possibly with myoplasty) because surgery in such cases is technically challenging and associated with a high risk of complications [3]. Comparing the long-term outcomes of conservative and surgical treatment for aspergilloma, Jewkes et al. observed significant differences in 5-year survival rates only in the group of patients with recurrent hemoptysis or at least one episode of serious bleeding from the bronchial tree. The 5 -year survival rate was $41 \%$ among patients treated conservatively and $84 \%$ among patients undergoing surgery. Among asymptomatic patients, the difference was not statistically significant (65\% vs. $75 \%)$. Therefore, the authors recommend surgical treatment for all patients with recurrent hemoptysis (even those with significantly elevated operative risk), while not excluding the use of conservative management in asymptomatic patients [12].

The surgical treatment of aspergillomas, especially complex ones, poses a significant technical challenge due to massive adhesions, the necessity of lung decortication, the lack of interlobar fissures, intensified fibrosis, and inflammatory reactions around the vessels of the lung's hilum. Consequently, the procedure lasts longer than lung resection due to lung cancer, the intraoperative and postoperative blood loss is relatively high, and so is the rate of postoperative complications. According to various authors, the mortality rate after such procedures currently ranges from $0.9 \%$ to $4.3 \%[3-5,9,10]$, even though it amounted to $43 \%$ in the 1970 s and 1980 s [13]. The quality of lung parenchyma remaining after resection is listed as one of the most important factors determining survival as, in many cases, the cause of death is either pneumonitis or chronic respiratory failure $[3,14]$. The rate of postoperative complications ranges from $25 \%$ to $70 \%$ (63.3\% in our material); most of them also result from technical difficulties and poor quality of the remaining lung parenchyma $[5,8]$. The most common complications listed in the literature are constituted by prolonged air leaks, residual pneumothoraces, and bleeding [3, 7]. The previously mentioned technical difficulties, the extent of fungal lesions in the lung, and the pathological changes in the lung parenchyma surrounding the aspergilloma cavity sometimes force the surgeon to perform a pneumonectomy. In our view, and in the opinion of most authors, the removal of a whole lung is associated with a very high risk of serious postoperative complications, especially in emaciated patients with marginal spirometric values $[15,16]$. Shiraishi et al. reported that $44 \%$ of their patients operated on due to aspergilloma required pneumonectomy; the mean duration of the procedure was $430 \mathrm{~min}$, and the mean intraoperative blood loss amounted to $1050 \mathrm{ml}$ [16]. According to Massard et al., 4 in 5 aspergilloma patients develop an empyema in the post-pneumonectomy cavity; the most important factor promoting its development is the opening of the aspergilloma cavity during the procedure [6]. Therefore, researchers underscore the importance of exercising caution during decortication and performing the extrapleural resection in such a way that the whole lesion is removed without opening the aspergilloma cavity. They also recommend strengthening the bronchial stump with a pedicled latissimus dorsi flap and, in some cases, performing concurrent thoracoplasty [16]. In our material, all 3 patients undergoing pneumonectomy required prolonged mechanical ventilation due to respiratory failure; 2 of them required repeat thoracotomy due to bleeding, 1 died during the postoperative period, and 1 developed an empyema.

The long-term results of surgical treatment for aspergilloma are encouraging. The rate of 5-year survival oscillates between $85 \%$ and $93 \%$ [3-5]. Most authors note the complete abatement of ailments, especially hemoptysis. Aspergillosis recurs in 5-7\% of patients undergoing surgery, most commonly due to: insufficient extent of the primary lung resection (usually wedge resection), the presence of post-tuberculous cavities or bronchiectases in the remaining lung parenchyma, and continuation of immunosuppressive treatment $[3,12]$. None of our patients undergoing resection experienced recurrence of fungal infection; how- 
ever, 3 patients were diagnosed with lung cancer during the follow-up. Two of them died due to neoplastic progression, while the third was successfully treated with surgery. The literature features reports of both aspergilloma development within a neoplastic tumor and the development of lung cancer after aspergilloma surgery $[3,17]$. The higher risk of lung cancer development in this group of patients is associated with the chronic use of immunosuppressants, the common concomitance of COPD, and the high proportion of smokers.

\section{Conclusions}

Due to the significant risk of postoperative complications, surgery for aspergilloma should be offered primarily to patients with intense symptoms (especially persistent hemoptysis) in whom resection smaller than pneumonectomy can be performed. In the case of emaciated patients with numerous comorbidities, alternative treatment methods should be considered (such as bronchial artery embolization or cavernostomy). Despite the high risk of postoperative complications, the long-term results of aspergilloma surgery are good in terms of the low rate of recurrence and long-term survival.

\section{Disclosure}

Authors report no conflict of interest.

\section{References}

1. Park CK, Jheon S. Results of surgical treatment for pulmonary aspergilloma. Eur J Cardiothorac Surg 2002; 21: 918-923.

2. Soubani AO, Chandrasekar PH. The clinical spectrum of pulmonary aspergillosis. Chest 2002; 121: 1988-1999.

3. Kim YT, Kang MC, Sung SW, Kim JH. Good long-term outcomes after surgical treatment of simple and complex pulmonary aspergilloma. Ann Thorac Surg 2005; 79: 294-298.
4. Brik A, Salem AM, Kamal AR, Abdel-Sadek M, Essa M, El Sharawy M, Deebes A, Bary KA. Surgical outcome of pulmonary aspergilloma. Eur J Cardiothorac Surg 2008; 34; 882-885.

5. Akbari JG, Varma PK, Neema PK, Menon MU, Neelakandhan KS. Clinical profile and surgical outcome for pulmonary aspergilloma: a single center experience. Ann Thorac Surg 2005; 80: 1067-1072.

6. Massard G, Roeslin N, Wihlm JM, Dumont P, Witz JP, Morand G. Pleuropulmonary aspergilloma: clinical spectrum and results of surgical treatment. Ann Thorac Surg 1992; 54: 1159-1164.

7. Lejay A, Falcoz PE, Santelmo N, Helms O, Kochetkova E, Jeung M, Kessler R, Massard G. Surgery for aspergilloma: time trend towards improved results? Interact Cardiovasc Thorac Surg 2011; 13: 392-395.

8. Babatasi G, Massetti M, Chapelier A, Fadel E, Macchiarini P, Khayat A, Dartevelle P. Surgical treatment of pulmonary aspergilloma: current outcome. J Thorac Cardiovasc Surg 2000; 119: 906-912.

9. Lee JG, Lee CY, Park IK, Kim DJ, Chung KY. Pulmonary aspergilloma: analysis of prognosis in relation to symptoms and treatment. J Thorac Cardiovasc Surg 2009; 138: 820-825.

10. Okubo K, Kobayashi M, Morikawa H, Hayatsu E, Ueno Y. Favorable acute and long-term outcomes after the resection of pulmonary aspergillomas. Thorac Cardiovasc Surg 2007; 55: 108-111.

11. Rafferty P, Biggs BA, Crompton GK, Grant IW. What happens to patients with pulmonary aspergilloma? Analysis of 23 cases. Thorax 1983; 38: 579-83.

12. Jewkes J, Kay PH, Paneth M, Citron KM. Pulmonary aspergilloma: analysis of prognosis in relation to haemoptysis and survey of treatment. Thorax 1983; 38: 572-578.

13. Daly RC, Pairolero PC, Piehler JM, Trastek VF, Payne WS, Bernatz PE. Pulmonary aspergilloma. Results of surgical treatment. J Thorac Cardiovasc Surg 1986; 92: 981-988.

14. Suen $\mathrm{H}$, Wright $\mathrm{C}$, Mathisen DJ. Surgical management of pulmonary aspergillosis. Chest Surg Clin N Am 1993; 3: 671-681.

15. Massard G, Dabbagh A, Kessler R, Barsotti P, Roeslin N, Morand G. Pneumonectomy for chronic infection is a high-risk procedure. Ann Thorac Surg 1996; 62: 1033-1038.

16. Shiraishi Y, Katsuragi N, Nakajima Y, Hashizume M, Takahashi N, Miyasaka Y. Pneumonectomy for complex aspergilloma: is it still dangerous? Eur J Cardiothorac Surg 2006; 29: 9-13.

17. Hanagiri T, Okabayashi K, Mitsudomi T, Noda Y, Hiratsuka M, Shirakusa T. Aspergilloma within cavitating pulmonary carcinoma. Scand J Thor Cardiovasc Surg 1993; 27: 57-60. 